\title{
Effect of Vacuum Frying Conditions on Quality of French Fries and Frying Oil
}

\author{
Esra Devseren, ${ }^{1}$ Dilara Okut, ${ }^{1}$ Mehmet Koç, ${ }^{2}$ Özgül Özdestan Ocak, ${ }^{1}$ \\ Haluk Karataş ${ }^{3}$ and Figen Kaymak-Ertekin ${ }^{1 \star}$ \\ ${ }^{1}$ Ege University, Faculty of Engineering, Department of Food Engineering, 35100, Bornova, Izmir, Turkey \\ ${ }^{2}$ Adnan Menderes University, Faculty of Engineering, Department of Food Engineering, 09010, Aydin, Turkey \\ ${ }^{3}$ Arçelik A. Ş., RßD Center, 34940, İstanbul, Turkey \\ * Corresponding author: E-mail: figen.ertekin@ege.edu.tr \\ Phone: +90.232.3113006 Fax: +90.232.3427592
}

Received: 02-06-2020

\begin{abstract}
Vacuum frying conditions were investigated with respect to physical, chemical and sensorial properties of French fries and frying oil, besides determining the effect of frying conditions in terms of frying temperature and time. In order to determine the optimum frying conditions of the French fries optimization study was carried out according to Central Composite Rotatable Design. The results were evaluated to determine optimum vacuum frying conditions targeting minimum oil content, $30-45 \mathrm{~N}$ in range of hardness, minimum acrylamide content and maximum overall preference. The optimum vacuum frying condition was selected as $124.39^{\circ} \mathrm{C}$ of frying temperature and $8.36 \mathrm{~min}$ of frying time for French fries. The French fries obtained at optimum conditions for vacuum frying preserved the desired color, textural properties and flavor and it has low oil content and reduced acrylamide formation. In addition, the frying oil quality was preserved with vacuum frying.
\end{abstract}

Keywords: French fries; vacuum frying; browning index; hardness; acrylamide; microstructure

\section{Introduction}

Deep fat frying is one of the earliest and most popular way of cooking process where the food is immersed into the hot oil $\left(150-200^{\circ} \mathrm{C}\right)$ at atmospheric pressure. Due to attractive color, texture and flavor of fried foods, deep fat frying is commonly applied both at home and in the food industry. ${ }^{1}$ Nowadays, deep fat frying has been remarkably interested by researchers due to rising consumption of fast food and pre-cooked food. Unfortunately, many studies related with deep fat frying reported that excessive oil uptake and high frying temperature had negative effects on health such as coronary heart diseases, cancer, diabetes and hypertension. ${ }^{2}$

As a result of simultaneous heat and mass transfer during deep-fat frying chemical and physical changes in foods have occurred for instance; moisture loss, oil uptake, crust formation, starch gelatinization and color change with the Maillard reaction, oxidation, hydrolysis and polymerization of oil. In addition to these changes, acrylamide was also formed during deep-fat frying process. ${ }^{3}$
Although consumer awareness of the relationship between nutrition and health increases, deep fat frying still continues to be one of the main cooking methods. ${ }^{4}$ That is why, the researchers have tried to develop alternative frying methods to eliminate the negative effects of deep fat frying and get healthier fried products.

Vacuum frying is one of the new technologies as an alternative to atmospheric pressure frying and it is performed by immersing the food into the oil in a closed system at pressures lower than atmospheric pressure. ${ }^{5,6}$ Even though vacuum frying process carried out under the pressure of 6.65 $\mathrm{kPa}^{7-10}$ it is increased up to $27.5 \mathrm{kPa}$ in some studies. ${ }^{6,11-12}$

The vacuum frying process is performed at low temperature in low-oxygen frying medium. ${ }^{9,13}$ Thus, the vacuum frying is superior to atmospheric frying in terms of the protection of nutritional composition, color and flavor of the fried product, reusability of frying oil and acrylamide formation. ${ }^{13}$ Acrylamide, classified as a potential carcinogen by the International Agency for Research on Cancer, is formed in foods rich in both carbohydrates and proteins 
during cooking process at high temperatures. ${ }^{14}$ Many studies in literature showed that vacuum frying of potato chips led to form less acrylamide compared to those of atmospheric pressure. ${ }^{3,15-16}$ Although reduction of acrylamide in vacuum fried products is clear, the effect of vacuum on oil uptake is highly complex. According to Garayo and Moreira, ${ }^{13}$ potato chips had $30 \%$ less fat content with vacuum frying than atmospheric frying, while the potato chips with similar color and textural properties obtained with both frying methods. In contrast to this study, Troncoso et al., ${ }^{8}$ found that vacuum frying resulted in an increase in oil content of potato chips compared to atmospheric frying.

The quality of frying oil is also an important parameter affecting the quality of the fried food. Limited number of studies have been in literature investigating the effect of vacuum application on quality of frying oil. ${ }^{9,17}$ Crosa et al., ${ }^{9}$ investigated the effect of vacuum frying and traditional frying on sunflower oil degradation, fatty acid composition and alpha-tocopherol content. It was determined a significant increase in the usage time of the oil with vacuum frying process compared with atmospheric frying process. Similarly, Aladedunye and Przybylski, ${ }^{17}$ reported that vacuum frying reduced the total polarity by $76 \%$ compared to atmospheric frying and lower oxidative degradation was observed. They also found that the rate of tocopherol degradation was three and twelve slower with vacuum frying than with other methods.

During frying, the texture of the fruits and vegetables becomes initial soft and then hard due to progressive development of a dehydration crust. In addition, there is less structural change with vacuum frying than with atmospheric frying. ${ }^{14}$ Visual observations in apple slices showed that the surface of vacuum fried products was less expanded than atmospheric frying. ${ }^{6}$ Dueik et al., ${ }^{18}$ determined that the maximum power of fried carrot chips is not affected by frying technology and temperature, so that vacuum fried chips have the same crispness as atmospheric fried ones. Da Silva and Moreira, ${ }^{19}$ did not found significant differences in the textural parameters of sweet potato, mango and green beans between atmospheric and vacuum frying.

In this study, a vacuum cooking equipment having frying function was developed to investigate the effect of frying conditions in terms of temperature and time on physical, chemical and sensorial properties of French fries and frying oil. In order to determine the optimum frying conditions (temperature and time), optimization study was carried out according to Central Composite Rotatable Design (CCRD) and the effects of the temperature and time of vacuum frying were investigated.

\section{Experimental}

\section{1. Material}

Frozen French fries and sunflower oil were obtained from a local supermarket in Izmir. Sunflower oil was select- ed as frying medium due to preferring mostly at home. Prior to frying process, frozen French fries were sorted with respect to their size $(1 \times 1 \times 8 \mathrm{~cm})$ and stored at $-24^{\circ} \mathrm{C}$. The moisture and oil content of the frozen French fries were determined $71.7 \pm 1.7 \%$ and $3.9 \pm 0.5 \%$, respectively.

\section{2. Developed Vacuum Frying Equipment}

The vacuum frying equipment was designed to allow frying at wide range of temperature and vacuum pressure. Tomruk et al..$^{20}$ already gave the constructional and working details of the equipment used in this study. The developed equipment consisted of three parts that were vacuum vessel, condenser and vacuum pump as shown in Fig. 1. The vacuum vessel was capacity of 6 liter and a basket, which can be moved up and down, was added to the vacuum vessel and it was difference from Tomruk et al. ${ }^{20}$. Also, a thermocouple (PT 100) was placed in the vacuum vessel to determine temperature of frying oil. Electrical heater was $1.5 \mathrm{~kW}$ and the vacuum pump $(0.55 \mathrm{Hp})$ was oily type. The condenser includes refrigerant (R-404a). In this developed equipment, while the vacuum level and cooking time were controlled by PLC system, the heater was programmed by PID control system.

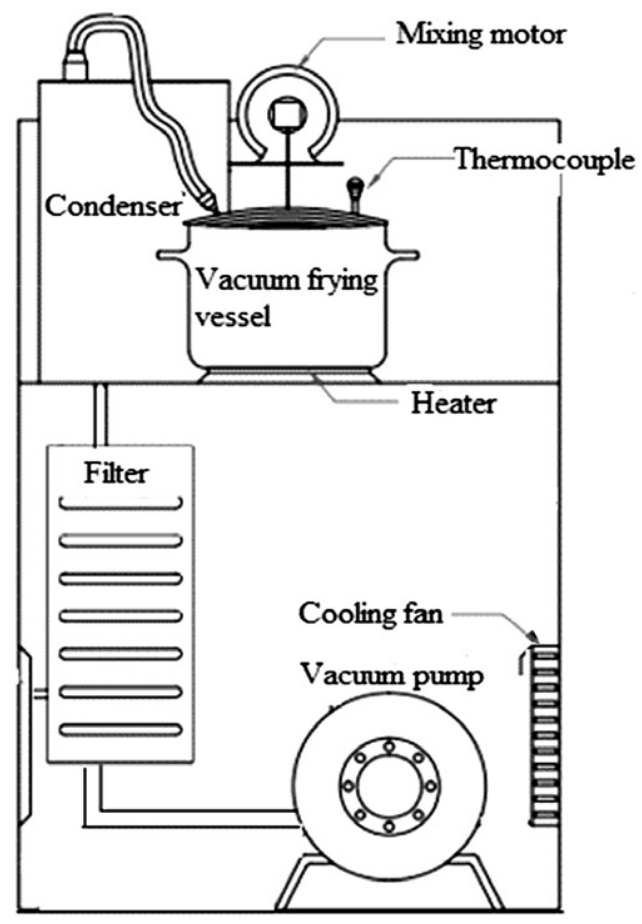

Fig. 1. Developed vacuum frying equipment

\section{3. Frying Process}

In this study, French fries were fried under vacuum. French fries to sunflower oil ratio was 1:6 (w/v). Vacuum frying process was consisted of eight steps: (1) heating oil to selected temperature, (2) loading of French fries in a bas- 
ket and closing the lid, (3) applying vacuum until $13.3 \mathrm{kPa}$, (4) immersing the French fries into the hot oil, (5) frying French fries for selected time, (6) lifting the basket from the oil, (7) waiting for 30 seconds to allow the surface oil flow down, (8) pressurizing the vessel.

The level of vacuum in this study was $13.3 \mathrm{kPa}$ for all vacuum frying experiments. This level of vacuum was maximum vacuum pressure can be applied in the developed equipment.

For vacuum frying experiments, French fries were fried at $120-150{ }^{\circ} \mathrm{C}$ for $5-15$ min according to Central Composite Rotatable Design (CCRD). Experimental CCRD design was given in Table 1 . All the frying experiments were done in duplicate.

\section{4. French Fries Analysis}

\section{Moisture Content}

For determination of moisture content in raw and fried French fries, samples were crushed with sand and dried in vacuum oven (Vacucell, U.S.A) at $65^{\circ} \mathrm{C}$ for $24-$ $48 \mathrm{~h}$ until constant weight. ${ }^{21}$

\section{Color}

Color of the raw and fried French fries were determined with a Minolta Chroma Meter (Konica Minolta, CR-400, Osaka, Japan). Hunter L, a, and b values were recorded to calculate the browning index (BI) of French fries (Eq. 1). ${ }^{22,23}$

$$
\begin{aligned}
B I= & ([100 *((a+1.75 L) /(5.645 L+ \\
& +a-3.012 b)-0.31)]) / 0.17
\end{aligned}
$$

\section{Texture}

The firmness of raw and fried French fries was measured by using the Texture Analyzer equipment (TA-XT2, Stable Micro Systems, UK) equipped with Multiple Chip Rig probe. Puncture test was simultaneously applied to 10 potato samples and the maximum power $(\mathrm{N})$ was recorded. Puncture test was performed under these conditions: pre-test speed: $2 \mathrm{~mm} / \mathrm{s}$, test speed: $1 \mathrm{~mm} / \mathrm{s}$, post-test speed: $10 \mathrm{~mm} / \mathrm{s}$, distance: $5 \mathrm{~mm}$ and trigger force: $20 \mathrm{~g}$.

\section{Acrylamide content}

Acrylamide content of French fries was analyzed with LC/MS-MS (ThermoFisher Scientific, USA). This method consisted of three sections, which were acrylamide standards preparation, sample preparation and purification. ${ }^{23}$

\section{Oil content}

Oil content of samples was gravimetrically determined by using hexane as the solvent with Soxhelet system. ${ }^{21}$

\section{Microstructure}

Microstructure of the raw and fried French fries were determined by using Micro Computer Tomography
(Micro-CT) equipment (Scanco Medical $\mu \mathrm{CT}$ 50, Switzerland). 3D models were created with the images received cross-section of the sample by using $\mathrm{X}$-rays. The average pore diameter $(\mu \mathrm{m})$ of the raw and fried samples were also measured. ${ }^{24}$

\section{Sensory evaluation}

Sensory properties of fried French fries were evaluated in terms of appearance, color, texture, flavor (taste and smell) and overall acceptance. Sensory analysis was performed according to Altuğ and Elmac1, ${ }^{25}$ with 10 panelists. All panelists were non-smokers. The intensity of the properties was determined using a 5 -point scale ( 1 being the lowest and 5 being the highest).

\section{5. Frying Oil Analysis}

\section{Free Fatty Acids}

Free fatty acids (FFA) content of frying oil was determined using a titrimetric method and expressed as free oleic acid percentage. ${ }^{26}$

\section{Peroxide Value (PV)}

Peroxide value (PV) expressed in milliequivalents of active oxygen per kilogram oil ( $\mathrm{mEq} \mathrm{O} 2 / \mathrm{kg}$ oil), was determined. ${ }^{26}$

\section{Total Polar Compounds (TPC)}

Total polar compounds estimation was based on dielectric constant changes directly measured on hot oil with Deep Frying Oil Tester testoT270, when frying oil temperature was approximately $80( \pm 5){ }^{\circ} \mathrm{C}$.

\section{Experimental Design and Statistical Analysis}

Response surface methodology (RSM) was used to investigate the main effects of frying temperature and time on physical, chemical and sensorial properties of French fries fried under vacuum and optimize the responses. All experimental data were fitted to a second-order polynomial model and regression coefficients were obtained for each response. Significant terms in the models were found by analysis of variance (ANOVA). Design Expert Ver. 7.0.0 (Stat-Ease, 2005) and were used to fit response surfaces, where significant differences $(p<0.05)$ were detected.

All of the analysis were done in triplicates. Results are shown as mean \pm standard deviation.

\section{Optimization}

Numerical methods (desirability function) were used for optimization. At least five attempts were carried out at the optimum point as determined by the model (the optimum process conditions) and the optimum point was confirmed experimentally. In this study, desirability functions were evaluated for the criteria of minimum oil content, $30-45 \mathrm{~N}$ in range of hardness, minimum acrylamide content and maximum overall preference. These criterions 
were chosen according the literature data. Furthermore, response surface graphs and contour lines that helps to determine the optimum point is plotted using models obtained by regression analysis.

\section{Results and Discussion}

\section{1. Effect of Vacuum Frying on French Fries}

The physical, chemical and sensorial properties of the French fries at different experimental conditions are given in Table 1.

ANOVA and regression analysis were evaluated to fit the model and determined the statistical significance of the model terms, as shown in Table 2. The quadratic polynomial model represented significantly the experimental values of responses at $\mathrm{p}<0.05$ level, besides the lack of fit of models were not significant. The counter plots of the predicted model of BI, hardness, oil content, acrylamide content, moisture content, overall acceptance, average pore diameter and peroxide value are given in Fig. 2.

Moisture content was an important quality criteria for fried foods due to its effect on final product texture, microstructure and sensorial acceptability. ${ }^{27}$ The moisture content of fried foods varied with initial moisture content and dimensions of the product, and frying temperature and time. ${ }^{24}$ The moisture content of French fries decreased with an increase in frying temperature and time as shown in Table 1. Garayo and Moreira, ${ }^{13}$ explained this circumstance as follows; the boiling point of water reduced with a decrease in pressure, so the water in the potato begun to vaporize faster under vacuum. Lisinska and Golubows$\mathrm{ka}^{28}$ have reported that French fries had a moisture content of $44.7 \%$ because of atmospheric frying at $180{ }^{\circ} \mathrm{C}$ for 7 min. Besides, Romani et al., ${ }^{29}$ observed that moisture content of French fries changed from $43.38 \%$ to $29.37 \%$ at $180^{\circ} \mathrm{C}$ for 10 min depending on type of fryer and potato to oil ratio. These results were in consistent with our findings for vacuum frying. The ANOVA results also showed that, the moisture contents of French fries fried under vacuum significantly changed with frying temperature and time as shown in Table 2 . In addition, it can be clearly seen in Fig.2.

The oil content of fried products was also one of the most important quality features in many ways such as number of calories supplied by the food and growing trend on consuming foods produced with healthier methods. Beside the health issues about oil consumption, it had specific functional effects on flavor, appearance and smooth mouthfeel, which contributes the sensorial quality of the product. ${ }^{30}$ For this reason, many studies focused on producing fried products with low oil content that still protecting the desirable texture and flavor. Oil absorption was affected by the quality of frying oil, frying temperature, time and pressure, shape and chemical composition of food and applied pre-treatments. ${ }^{4}$ In literature, critical

\begin{tabular}{|c|c|}
\hline 픙 & 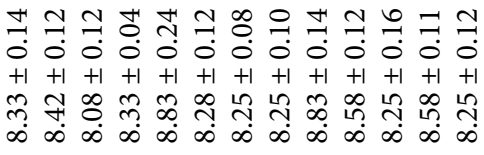 \\
\hline 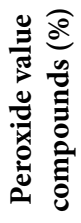 & 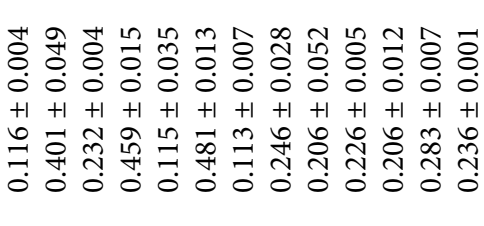 \\
\hline 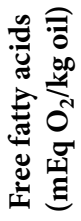 & 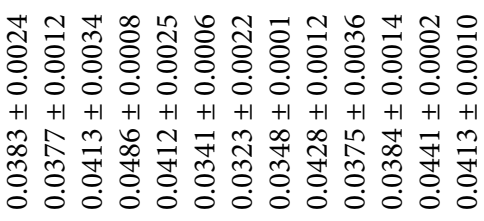 \\
\hline 要 & 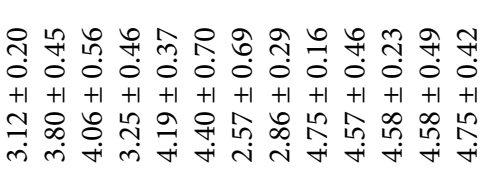 \\
\hline 苋 & 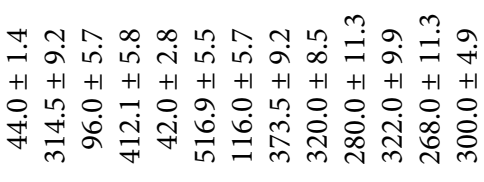 \\
\hline 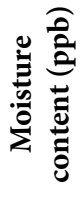 & 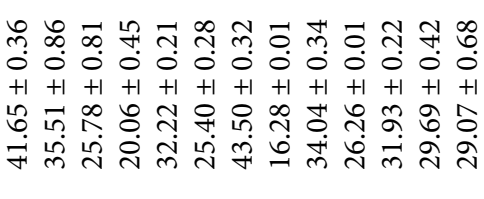 \\
\hline 节 & 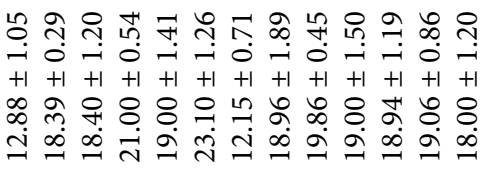 \\
\hline 赵 & 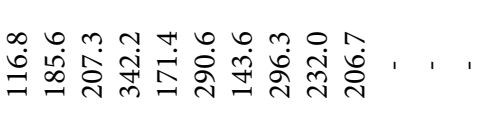 \\
\hline$\underset{\Xi}{\tilde{z}}$ & 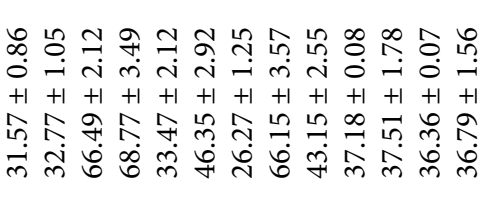 \\
\hline & 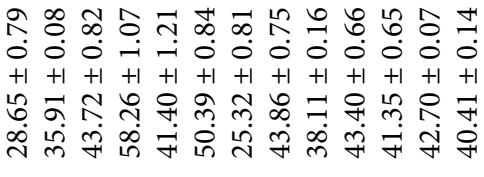 \\
\hline$\stackrel{\Xi}{\Xi}$ & 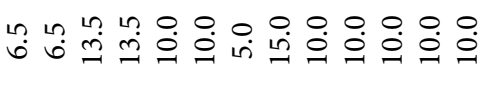 \\
\hline 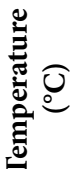 & 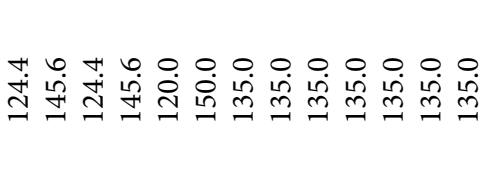 \\
\hline
\end{tabular}




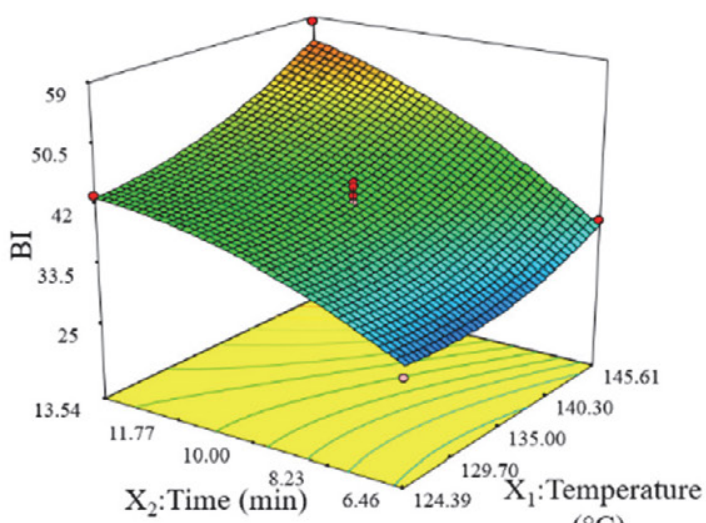

$\left({ }^{\circ} \mathrm{C}\right)$

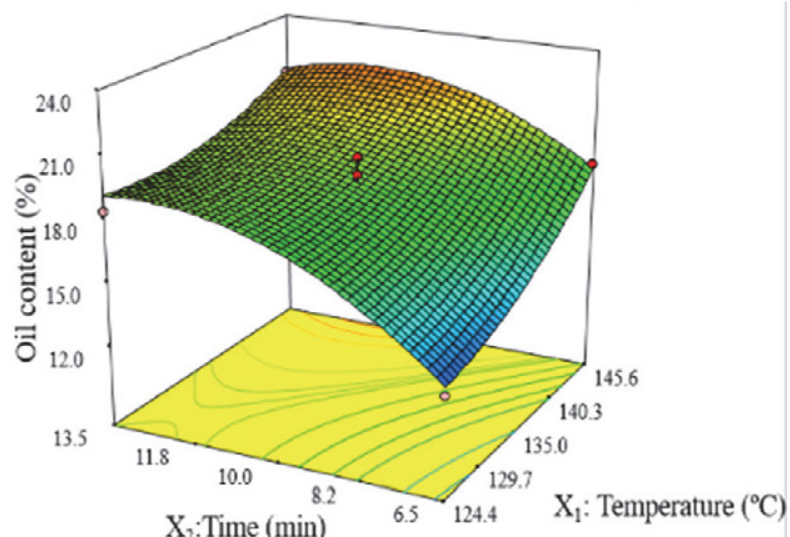

$\mathrm{X}_{2}$ :Time (min)

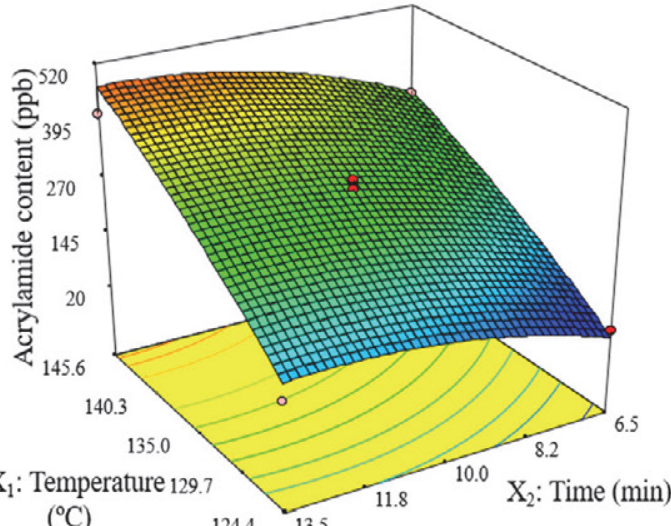

$\left({ }^{\circ} \mathrm{C}\right)$

$124.4 \quad 13.5$

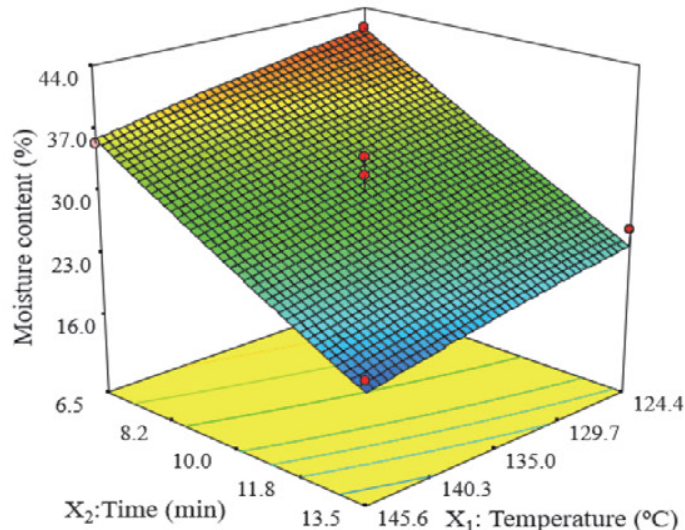

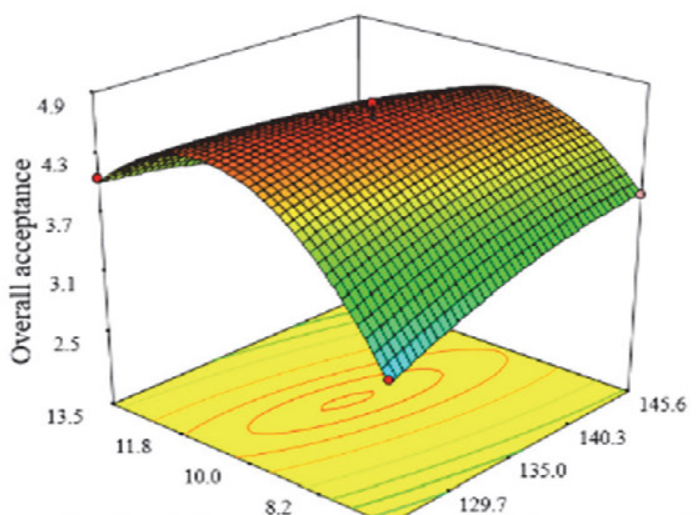

$\mathrm{X}_{2}$ : Time (min) ${ }^{8.2} \quad{ }_{124.4}^{129.7} \quad \mathrm{X}_{1}$ : Temperature $\left({ }^{\circ} \mathrm{C}\right)$

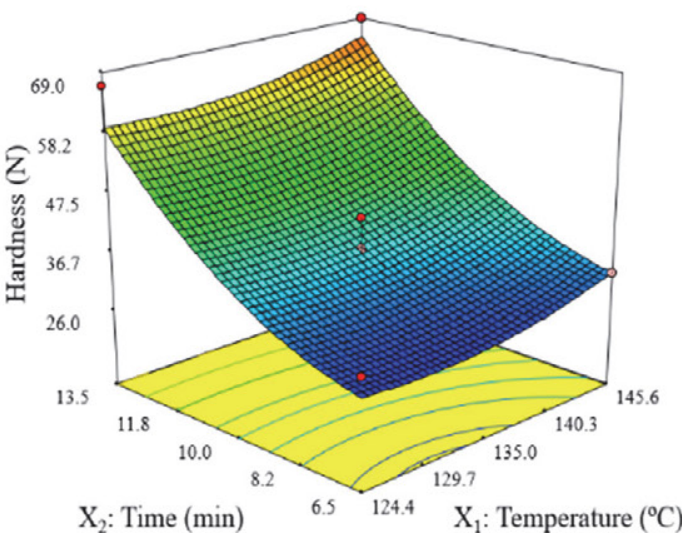

$\mathrm{X}_{2}$ : Time (min) $\quad 6.5 \quad 124.4 \quad \mathrm{X}_{1}$ : Temperature $\left({ }^{\circ} \mathrm{C}\right)$
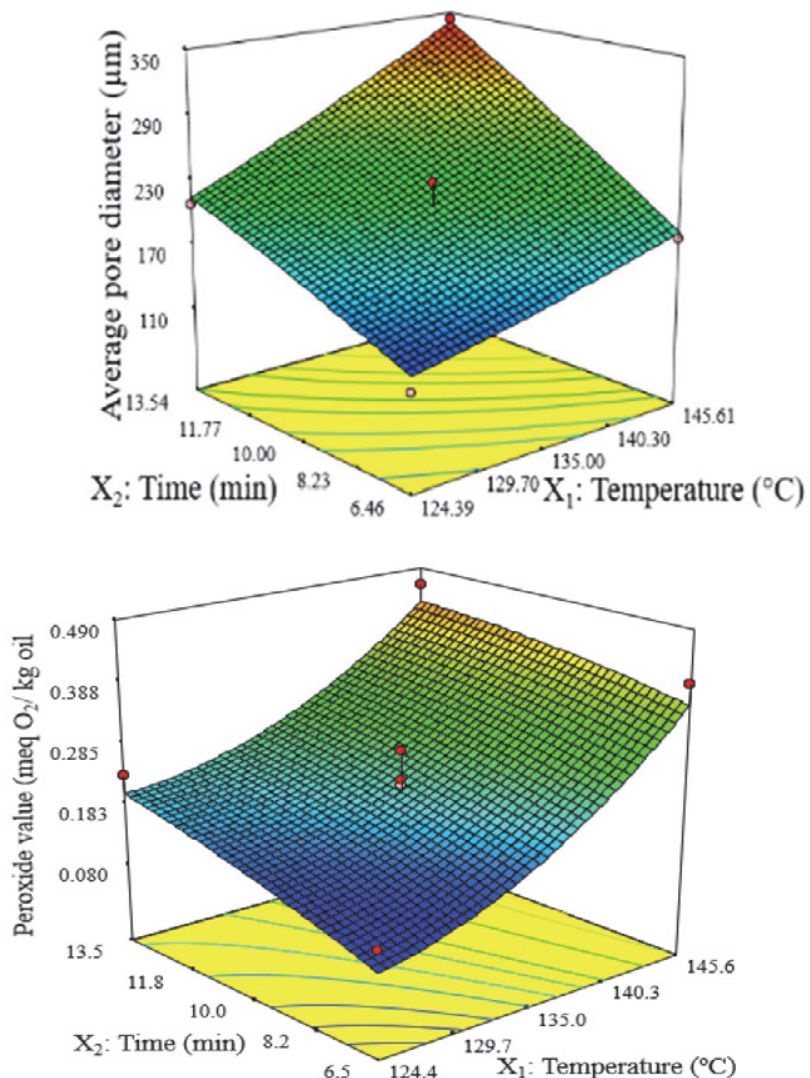

Fig. 2 Response surface graphics and isohips curves for the quality characteristic of vacuum fried French fries 


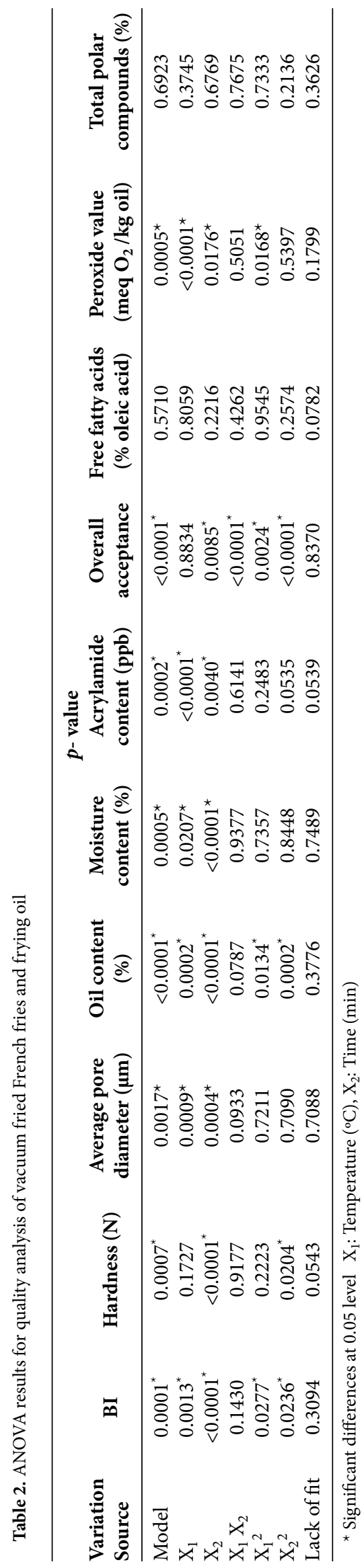

temperatures for frying which were important for ensuring desirable structural and textural properties of the fried product were stated as 160 and $180^{\circ} \mathrm{C}^{31}$ Pedreschi and Moyano, ${ }^{32}$ found that increase in frying temperature resulted in a decrease in the oil absorption. This was occurred by the reason of that the surface of the food dried faster and a crust formed, which acted as a barrier to the absorption of oil at high temperature. ${ }^{33}$

The literature data indicated that vacuum frying decreased oil content, even though it occurred at low temperatures. ${ }^{6,13,15}$ For vacuum frying, Fig. 2 showed that the oil content of French fries increased with increasing frying temperature and time. The lowest oil content (12.9\%) was observed at $135{ }^{\circ} \mathrm{C}$ for $5 \mathrm{~min}$ (Table 1). Oil content of French fries was significantly affected by frying time and temperature $(\mathrm{p}<0.05)$ (Table 2).

Troncoso et al., ${ }^{8}$ determined that oil content of vacuum fried potato chips was higher than atmospheric fried chips whereas Garayo and Moreira ${ }^{13}$, Da Silva and Morei$\mathrm{ra}^{19}$ and Dueik et al., ${ }^{34}$ reported that vacuum fried potato chips contained less oil compared to atmospheric frying chips. Furthermore, it was determined that by centrifuging the fried product after vacuum frying process resulted in $70-81 \%$ reduction in oil content. ${ }^{10,35}$

Color of fried foods was also an important physical quality attribute generally considered when making a decision to consume the product. The color of French fries was developed as a result of Maillard reaction, which was mainly dependent on chemical composition of raw material and frying conditions in terms of temperature and time. ${ }^{36}$ In this study, the color alternation of French fries caused by either frying conditions or frying methods was evaluated with Browning index (BI). Because the BI was considered as a reliable indicator of acrylamide concentration. ${ }^{23}$ The results showed that the higher frying temperature and/or the longer frying time resulted in the higher BI. Because the color development mechanism for Frenchfries in thermal processing was dependent upon the rate of heat transfer. Vacuum fried vegetables and fruits had lower color changes and lighter color than atmospheric fried products. ${ }^{6,8,16,19}$ In case of high heat rates in atmospheric frying, the color of French fries turned rapidly to brown. ${ }^{37}$ However, in the vacuum frying method, low frying oil temperature resulted in slowing down the rate of heat transfer to the interior of food and the color of food products was preserved. Moreover, Moyano et al., ${ }^{38}$ found out that moisture content and color changes of French fries was highly correlated to each other. The similar results were also observed in $\mathrm{BI}$ and moisture content relations in this study.

The ANOVA results (Table 2) also showed that BI was significantly affected by frying temperature and frying time for vacuum frying $(p<0.05)$. Diamante et al., ${ }^{39}$ also observed the similar effect of frying temperature and time on $B I$ value of vacuum fried gold kiwifruit slices. However, the effect of frying temperature on BI is limited for short frying 
times in vacuum frying method (Fig. 2). The maximum value of $\mathrm{BI}(58.26)$ was observed at $145.6^{\circ} \mathrm{C}$ for $13.5 \mathrm{~min}$ in vacuum fried French fries (Table 1). As far as BI results were concerned, vacuum frying protected the desired color of French Fries. Because the natural color and flavor of food product could be preserved during vacuum frying due to frying at low temperature and low oxygen content. Da Silva and Moreira, ${ }^{19}$ studied with different fruits and vegetables to determine the effect of vacuum frying on their physical and chemical properties and they found out that most of the products retained their natural colors.

For frying process, the size of food is another important parameter affecting the oil content and colour of fried food. Studies have shown that the oil absorption increases as the thickness of the product decreases and the surface area increases. ${ }^{40}$ The best example of this is that French fries absorb less oil than potato chips due to their smaller surface area / volume ratio. ${ }^{41}$ Similarly, Guillaumin ${ }^{42}$ and Krokida et al. ${ }^{43}$ reported that there was a linear relationship between the thickness of potato chips and the amount of oil absorbed. Higher oil content as thickness decreases has been determined for potato chips. Also, the color change phenomenon gets more intense at smaller sample thickness. As thickness of French Fries was considered, lower thickness resulted in lower lightness and higher yellow color of the product. ${ }^{43}$ There are no studies examining the effect of food size for vacuum frying in the literature, but studies for atmospheric frying are sufficient to understand the effect of food size.

The texture of French fries was analyzed considering hardness, which was the maximum force $(\mathrm{N})$ needed to penetrate the probe into sample. The changes in the hardness of French fries with respect to frying temperature and time were given in Table 1 for vacuum frying. The hardness of French fries increased with increasing frying temperature and time. The hardness of French fries was only affected by frying time in vacuum frying $(p<0.05)$ (Table 2 ). The $3-D$ response surface graph of hardness also approved the sole effect of frying time on hardness of vacuum fried French fries (Fig 2).

In the literature, there were different results about the effect of frying methods mainly atmospheric and vacuum frying. Troncoso et al., ${ }^{8}$ studied on vacuum fried potato chips and determined that the values of hardness and crispiness of chips were decreased by vacuum frying. In contrast, Mir-Bel et al., ${ }^{12}$ indicated that vacuum fried dough had a much crunchier texture compared to atmospheric fried dough. However, Da Silva and Moreira, ${ }^{19}$ Dueik et al., ${ }^{18}$ and Moreira et al., ${ }^{35}$ observed no significant differences in the texture of vegetables prepared by atmospheric and vacuum frying processes. In addition to frying method, the frying conditions, the chemical composition of fried sample, the size and thickness of fried sample, the kind of oil used as frying medium should also take a consideration during interpreting the texture of fried samples. Indeed, Kita and Lisinska, ${ }^{44}$ found out that the type of fry- ing medium significantly affected the texture of French fries.

As previously mentioned, the moisture content of French fries had directly effect on textural properties of French fries. The highest hardness value for vacuum fried sample $(68.8 \mathrm{~N})$ was observed at $145{ }^{\circ} \mathrm{C}$ for $13.5 \mathrm{~min}$ and this sample also had the lowest moisture content (20.1\%). In order to highlight the effect of the moisture content on hardness, Pearson correlation tests were evaluated for vacuum frying. The results of these tests showed that hardness of vacuum fried French fries were inversely correlated with the moisture content, and the correlation coefficients (r) of vacuum fried French fries were found as -0.827 .
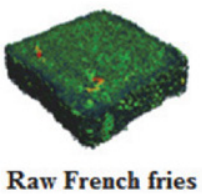

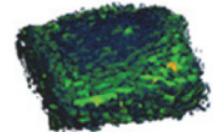

$124.4^{\circ} \mathrm{C}, 6.5 \mathrm{~min}$

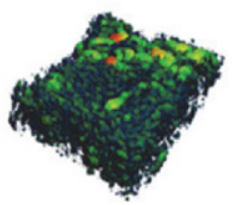

$145.6^{\circ} \mathrm{C}, 13.5 \mathrm{~min}$

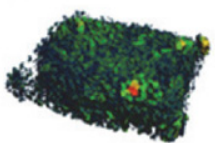

$135^{\circ} \mathrm{C}, 5 \mathrm{~min}$

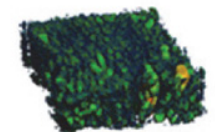

$145.6^{\circ} \mathrm{C}, 6.5 \mathrm{~min}$

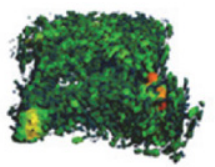

$120^{\circ} \mathrm{C}, 10 \mathrm{~min}$

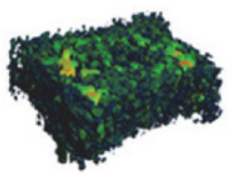

$135^{\circ} \mathrm{C}, 15 \mathrm{~min}$

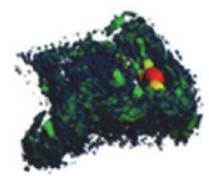

$124.4^{\circ} \mathrm{C}, 13.5 \mathrm{~min}$

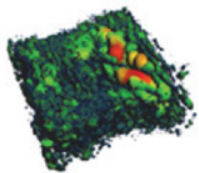

$150^{\circ} \mathrm{C}, 10 \mathrm{~min}$

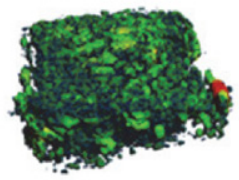

$135^{\circ} \mathrm{C}, 10 \mathrm{~min}$

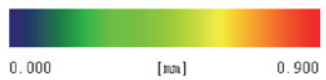

Fig. 3. Micro-CT images of vacuum fried French fries

The physical structure of fried products changed because of simultaneous heat and mass transfer during frying process. These changes played a key role in fat absorption and formation of textural structure. ${ }^{45,46}$ That is why, the structural changes in French fries during frying was analyzed with Micro Computer Tomography (Micro-CT) in this study. Micro-CT images of vacuum fried French fries are shown in Fig. 3. In these images, the change of colors from blue to red indicated to enlarge the pore diameter of French fries. Alam and Takhar, ${ }^{24}$ also found that the pore diameter of deep fat fried potato increased with increasing frying time while the total number of pores decreased. 
The average pore diameters of vacuum fried French fries enlarged with increasing frying time and temperature, and ranged between 116.8 and $342.2 \mu \mathrm{m}$. As mentioned above, the microstructure namely average pore diameter had a key role on texture and oil absorption. Thus, Pearson correlation test was applied between the pore diameter values and the hardness and oil content of vacuum fried French fries. The correlation coefficient values (r) were 0.788 for hardness and 0.794 for oil content at vacuum frying. Bouchon et al., ${ }^{46}$ explained the oil absorption mechanism in deep fat frying of potato that was directly dependent upon microstructure as follow; suction of oil into the porous crust region after removing of potato from frying medium and the competition between capillary suction of oil into the crust region and drainage of oil along the surface of the product.

Using frozen or non-frozen potato in the frying process can cause some effect on the fried product. If non-frozen potatoes are used, the temperature difference between the oil and the product decreases and crust occurs slower than for the frozen ones. The slower crust formation causes the product to absorb more oil. Also, Grop ${ }^{47}$ explained that one of the factors influencing acrylamide formation during frying is whether the food is fresh or frozen. French fries prepared from fresh potato contained more than the double the level of acrylamide compared with those from frozen potato.

Pedreschi et al., ${ }^{48}$ determined that acrylamide content of potatoes increased about 58 times due to an increase in the frying temperature from $120^{\circ} \mathrm{C}$ to $150{ }^{\circ} \mathrm{Cat}$ atmospheric pressure. There were many studies indicating that increasing temperature caused higher acrylamide content during frying of potato products. ${ }^{48}$

The amount of acrylamide in vacuum fried French fries varied between 42.0 and $516.9 \mathrm{ppb}$ under different operating conditions (Table 1). It could be clearly seen in Fig. 2 and ANOVA analysis (Table 2), the acrylamide content of French fries was significantly affected by the frying temperature and time $(p<0.05)$ and it increased with increasing frying temperature and time. Surdyk et al. ${ }^{49}$ and Brathen and Knutsen, ${ }^{50}$ also observed a strong correlation between acrylamide formation and the baking temperature and time. The 3-D counter plot of acrylamide content also demonstrated the effect of frying temperature and time (Fig. 2). In addition, it has been determined that frying temperature was more effective on acrylamide content than frying time. The highest acrylamide content (516.9 $\mathrm{ppb})$ was detected at the highest temperature $\left(150^{\circ} \mathrm{C}\right)$ for 10 min of frying time. This indicated that frying temperature was the most effective parameter for acrylamide formation.

Ölmez et al., ${ }^{51}$ investigated the acrylamide content of atmospheric fried foods in Turkey and stated that the highest acrylamide content was found in potato chips (59-2336 $\mathrm{ppb}$ ) and the secondly was in French fries (355-436 ppb). Granda et al., ${ }^{15}$ examined the acrylamide content in potato chips fried at atmospheric $\left(150,165\right.$ and $\left.180^{\circ} \mathrm{C}\right)$ and vacuum frying conditions $\left(118,125\right.$ and $\left.140^{\circ} \mathrm{C}, 1.3 \mathrm{kPa}\right)$. The acrylamide content of chips was found in the range of 358 $5021 \mathrm{ppb}$ at $165^{\circ} \mathrm{C}$ for 4 minutes of atmospheric frying and $25-437 \mathrm{ppb}$ at $118^{\circ} \mathrm{C}$ for 8 minutes of vacuum frying. Similarly, reduction in acrylamide content with vacuum frying was determined as $39-60 \%$ while frying of shrimp compared to atmospheric frying. ${ }^{16}$ In this study, the reduction in acrylamide content with vacuum frying of French fries was found between $36 \%$ and $96 \%$ at $10 \mathrm{~min}$.

It is well known that the formation of acrylamide is related with Maillard browning reaction and content of reducing sugar and asparagine in the potato product. ${ }^{52}$ Because of the relation of Maillard browning reaction and acrylamide formation, colour values can be utilized as an indicator of acrylamide formation. Many studies have pointed out that there was a correlation between the acrylamide content and colour of fried potatoes. ${ }^{36,48,53} \mathrm{In}$ our study, similar to literature, it was determined that as the browning index increased higher acrylamide content was determined in fried French fries. According to correlation analysis, the acrylamide content and the browning index gave a correlation of $r=0.64$ in vacuum fried French fries.

In addition, there is a relationship between the acrylamide content and the moisture and oil contents and the pore diameters of the samples. The acrylamide content of the samples increased by increasing the oil content and decreased by the increase in moisture content. The increase in pore diameters of samples also showed a positive correlation with the increase of acrylamide content. As previously mentioned, the moisture content of the samples decreased after the frying process at high temperatures and long processing times, while the oil contents and pore diameters were growing. These changes in oil and moisture content and pore diameter were also effective on the acrylamide content of the samples. Acrylamide generally formed at high temperatures and low moisture conditions related with frying, baking, and roasting. ${ }^{54}$ During the frying process, most of the heat energy transferred from oil to food in order to evaporate the moisture in the food. With the prolongation of the frying process, especially the moisture content of the food surface decreases, but the heat transfer from the oil to the food continues and the temperature of the food rises above the wet bulb temperature. Thus, the proteins and sugars that make up the dry matter of the food are exposed to high temperatures, and the formation of compounds such as acrylamide takes place. Gökmen et al., ${ }^{54}$ also reported that acrylamide formed even at temperatures below $120^{\circ} \mathrm{C}$ when the moisture content becomes adequately low upon prolonged frying. At high temperature frying process, rapid evaporation on the surface of the food can provide the necessary conditions for acrylamide formation.

Depending on potato cultivars, there are difference in dry matter, starch, protein ratio, phosphorus com- 
pounds, amylose, amylopectin ratio, total sugar, sucrose and ascorbic acid content. In previous studies, it was found that the oil content, acrylamide formation and colors of fried potato differ according to the potato cultivars. ${ }^{55-56}$ The reducing sugars and asparagine, as acrylamide precursors, are very important for reducing the acrylamide content in fried potato products. ${ }^{57}$ So, the selection of the potato cultivar is very important to reduce acrylamide formation. ${ }^{58}$ Some cultivars are more suitable than others for frying, due to the low reducing sugar content. Yang et al. ${ }^{56}$ evaluated three potato cultivars to investigate acrylamide formation during frying and they determined that the composition of the fresh potato cultivar is the primary factor in the formation of acrylamide. Additionally, fried potato color is the result of the Maillard reaction that depends on the content of reducing sugars and amino acids or proteins at the surface, and the temperature and time of frying. So, the cultivars of potato have effect on color of fried potatoes, as acrylamide content. ${ }^{59}$ Moreover, dry matter content of potato can be change depending on cultivars and oil uptake of fried potato products is known to have a highly significant negative relationship with dry matter content. Kaur et al. ${ }^{60}$ evaluated 5 different cultivars of potato and the cultivars with higher dry matter content showed lower oil uptake.

The consumer perceived the sensory quality as food quality. Sensory evaluation was used to determine the quality of both the raw material and the final product. In this study, the sensorial quality of vacuum fried French fries represented as overall acceptance, which was determined considering appearance, color, texture and taste of French fries.

The overall acceptance scores of vacuum fried French fries as sensorial quality are given in Table 1. It was found that the most effective independent variable on the overall acceptance values was frying temperature until $10 \mathrm{~min}$; afterward the overall acceptance value decreased possibly due to the browning of the color, losses in texture and taste of burnt flavor in vacuum fried French fries (Fig. 2). The region where the response surface curves had a circular shape showing the highest score of the overall acceptance and it was determined as 4.75 score for frying at $135^{\circ} \mathrm{C}$ for $10 \mathrm{~min}$. Frying temperature did not have a significant effect on the overall acceptance of vacuum fried French fries compared to the frying time. This result was also coherent with ANOVA results (Table 2).

\section{2. Effect of Vacuum Frying on Frying Oil}

During frying process, oil undergoes to chemical deterioration. This leads to the formation of more polar compounds than the triacylglycerol's of frying oil. These are called total polar material (TPM), and concentration of TPM is considered as an indicator of the quality of frying oil. ${ }^{61}$ The amount of TPM depend on processing conditions as frying temperature, frying time, oxygen and water content of food. ${ }^{62}$ Because TPM is harmful for human healthy, some countries have a limit of TPM in frying oil. The limit of TPM is $25 \%$ in France, Turkey, Belgium, Italy, Spain and South Africa, while it is $27 \%$ in Austria and Germany. ${ }^{63,64}$ According to Table 1, the total polar material content of the frying oils obtained at the end of the frying process varies between $8.25 \%$ and $8.83 \%$. Although different frying time and temperature were applied, the total polar material contents of frying oils were found to be very close to each other. According to ANOVA analysis, the effect of frying time and temperature was not significant statistically $(p>0.05)$. In addition, the frying oil has a polar substance content of 8.08 $\pm 0.20 \%$ before frying process, this was indicated that the vacuum frying process does not produce significant differences in the total polar material content. In our study, the results of the total polar material content were found to be in accordance with the current regulation of frying oil in all countries.

The free fatty acid content of the frying oil is widely used as an indicator of oil degradation. Free fatty acidity can be followed quickly and reliably during frying. ${ }^{65}$ It is usually formed by the decomposition of triglycerides as a result of hydrolysis in the oil with the effect of air and humidity at high temperature. ${ }^{66}$ According to the frying oil regulation in Turkey, the acids number can be maximum $2.5 \mathrm{mg} \mathrm{KOH} / \mathrm{g}$ oil. ${ }^{64}$ The acids number is equal to two times free fatty acids content. This limit value may vary between countries. The maximum permissible free fatty acid values of some countries are as follows; $1.25 \%$ in Austria , 2.5\% in Belgium, 1\% in Germany, $1.25 \%$ in Japan and $2.25 \%$ in the Netherlands. ${ }^{67}$ In addition, frying oil is changed according to the free fatty acid content in the industry and the point determined for changing the oil varies depending on the product. This value is $0.5 \%$ for potato chips and $1 \%$ for French fries.

The effects of vacuum frying process variables on the free fatty acid content of frying oil were investigated and the free fatty acid content of frying oil were found between $0.0323 \%$ and $0.0486 \%$ oleic acids. These values were very close to each other. The free fatty acid content of the oil was determined as $0.0310 \pm 0.0019 \%$ before frying process. It was observed that the free fatty acid content of the oil increased with the frying process, but the frying oil was suitable for reuse according to the regulations.

According to ANOVA analysis, the effect of vacuum frying process conditions on the free fatty acidity of frying oil could not be explained by the selected quadratic model $(p>0.05)$. This is because the values of free fatty acid of frying oils are very close to each other. Frying temperature and time did not have a significant effect on the free fatty acid content of vacuum frying oil (Table 2).

The peroxide value increases with the progression of primary oxidation in oil. As oxidation progresses, primary oxidation products (hydroperoxide) are broken down to 
produce secondary oxidation products (aldehydes and ketones). ${ }^{9}$ Therefore, while peroxide value give information about the quality of the oil, but it is insufficient in determining the usage period of the oil.

The peroxide value of the frying oil at different temperatures and times under vacuum, are given in Table 1 . When the peroxide values were examined, it was determined that increasing in temperature and time increased the peroxide values, but the effect of time was very low. It was observed that the values of peroxide varied between 0.113 and 0.481 meq $\mathrm{O}_{2} / \mathrm{kg}$ and the highest value was reached in the condition at the highest temperature $\left(150^{\circ} \mathrm{C}\right)$. According to the results of variance analysis, the effect of temperature and time of the frying oil on the peroxide number was statistically significant $(\mathrm{p}$ $<0.05)$.

\section{3. Optimization}

The results were evaluated by using Design Expert version 7.0-packaged software and optimum vacuum frying conditions targeting minimum oil content, $30-45 \mathrm{~N}$ in range of hardness, minimum acrylamide content and maximum overall preference.

Second-order polynomial model was used for each response for determining the optimum point. The desirability function approach was applied to obtain the optimum point solution given in Table 3. The optimum vacuum frying condition was selected as $124.39^{\circ} \mathrm{C}$ of frying temperature and $8.36 \mathrm{~min}$ of frying time for French fries frying. The oil content, hardness, acrylamide content and overall preference at optimum conditions were predicted as $16.35 \%, 32.03 \mathrm{~N}, 87.4 \mathrm{ppb}$ and 4.09 , respectively. The results of the five validation experiments at optimum vacuum frying conditions are also given in Table 3, comparatively as average results and the estimated values. The oil content, hardness, acrylamide content and overall preference of the obtained samples were found to be significant $(\mathrm{p}<0.05)$ different from the predicted values determined by Design Expert. It was determined that the hardness value was within the defined limits $(30-45 \mathrm{~N})$, but it was higher than the predicted value. Overall preference score was found to be higher than the predicted value, oil content and acrylamide content were obtained to be lower than the predicted values. These indicated a considerable increase in positive way.

\section{Conclusion}

Vacuum frying methods were applied to investigate the effect of frying conditions on physical, chemical and sensorial quality of French fries. That is why a vacuum frying equipment prototype was designed to work under both vacuum and atmospheric pressure. Effect of frying independent variables (temperature and time) on French fries and frying oil was investigated according to CCRD experimental design. In addition, vacuum frying process conditions in terms of frying temperature and time were optimized to produce French fries with targeting minimum oil content, 30-45 $\mathrm{N}$ in range of hardness, minimum acrylamide content and maximum overall preference. The optimum vacuum frying condition was selected as $124.39^{\circ} \mathrm{C}$ of frying temperature and $8.36 \mathrm{~min}$ of frying time for French fries frying. The results showed that vacuum frying method protected the characteristic color, texture and sensorial quality of French fries, while the acrylamide content of French fries was low. The encountered problems, when targeted to achieve the desired color and texture in French fries frying at atmospheric frying, such as high acrylamide content, darkening of color and high oil content could be eliminated with vacuum frying. As a conclusion, vacuum frying can produce French fries containing low acrylamide content but having the same quality characteristics with those obtained under the atmospheric frying.

\section{Acknowledgements}

Funding provided by Ministry of Science, Industry and Technology, Republic of Turkey SAN- TEZ project (Project no: 0724.STZ.2014) and Arçelik A.Ş is appreciated.

\section{References}

1. R. G. Moreira, J. Palau, X. Sin, J Food Process Eng. 1995, 18, 307-320. DOI:10.1111/j.1745-4530.1995.tb00369.x

2. D. Dana, I. S. Saguy, Adv Colloid Interfac, 2006, 128-130, 267-272. DOI:10.1016/j.cis.2006.11.013

3. C. Granda, R. G. Moreira, J Food Process Eng, 2005, 28, 478493. DOI:10.1111/j.1745-4530.2005.034.X

4. I. Saguy, D. Dana, J Food Eng, 2003, 56, 143-152. DOI:10.1016/S0260-8774(02)00243-1

Table 3. Results of statistical analysis for verification the optimization results

\begin{tabular}{lcccrrr}
\hline Responses & Predicted value & Experimental value $^{\mathbf{a}}$ & SE $^{\mathbf{b}}$ & Difference & \% Error $^{\mathbf{c}}$ & $\boldsymbol{p}^{\text {-value }}$ \\
\hline Hardness (N) & 32.03 & $37.95 \pm 1.38$ & 0.619 & 5.92 & 15.60 & 0.001 \\
Overall acceptance & 4.09 & $4.51 \pm 0.17$ & 0.076 & 0.42 & 9.41 & 0.005 \\
Acrylamide content (ppb) & 87.4 & $65.1 \pm 3.9$ & 1.739 & -22.32 & 34.28 & 0.000 \\
Oil content (\%) & 16.35 & $13.18 \pm 1.27$ & 0.569 & -3.16 & 24.01 & 0.005 \\
\hline
\end{tabular}

${ }^{a}$ Experimental values were given as mean \pm standard deviation ${ }^{b}$ Mean standard error $c \%$ Error $=\left(\left|y_{\exp }-y_{\text {pre }}\right| / y_{\exp }\right)^{\star} 100$ 
5. L. M. Diamante, S. Shi, A. Hellmann, J. Busch, Int Food Res J, 2015, 22(1), 15-22.

6. M. Mariscal, P. Bouchon, Food Chem, 2008, 107, 1561-1569. DOI:10.1016/j.foodchem.2007.09.031

7. R. G. Moreira, Eur J Lipid Sci Technol, 2014, 116, 723-734. DOI:10.1002/ejlt.201300272

8. E. Troncoso, F. Pedreschi, R. N. Zuniga, LWT-Food Sci Technol, 2009, 42, 187-195. DOI:10.1016/j.lwt.2008.05.013

9. M. J. Crosa, V. Skerl, M. Cadenazzi, L. Olazábal, R. Silva, G. Suburú, M. Torres, Food Chem, 2014, 146, 603-607.

DOI:10.1016/j.foodchem.2013.08.132

10. A. Pandey, R. G. Moreira, J Food Process Eng, 2012, 35, 863873. DOI:10.1111/j.1745-4530.2011.00635.x

11. J. Mir-Bel, R. Oria, M. L. Salvador, J Food Eng, 2009, 95, 416422. DOI:10.1016/j.jfoodeng.2009.06.001

12. J. Mir-Bel, R. Oria, M. L. Salvador, Int J Food Sci Technol, 2013, 48, 2042-2049.

13. J. Garayo, R. Moreira, J Food Eng, 2002, 55, 181-191. DOI:10.1016/S0260-8774(02)00062-6

14. A. Andrés-Bello, P. García-Segovia, J. Martínez-Monzó, Food Eng Rev, 2011, 3, 63-78. DOI:10.1007/s12393-011-9037-5

15. C. Granda, R. G. Moreira, S. E. Tichy, J Food Sci, 2004, 69, 405-411. DOI:10.1111/j.1365-2621.2004.tb09903.x

16. G. Pan, H. Ji, S. Liu, X. He, LWT-Food Sci Technol, 2015, 62, 734-739. DOI:10.1016/j.lwt.2015.01.007

17. F. Aladedunye, R. Przybylski, Eur J Lipid Sci Technol, 2009, 111(9) 893-901. DOI:10.1002/ejlt.200900020

18. V. Dueik, P. Robert, P. Bouchon, Food Chem, 2010, 119, $1143-$ 1149. DOI:10.1016/j.foodchem.2009.08.027

19. P. F. Da Silva, R. G. Moreira, LWT-Food Sci Technol, 2008, 41, 1758-1767. DOI:10.1016/j.lwt.2008.01.016

20. D. Tomruk, E. Devseren, M. Koç, Ö. Ö. Ocak, H. Karataş, F. Kaymak-Ertekin, Agron Res, 2016, 14(S2), 1475-1487.

21. AOAC, Association of official methods of analysis methods 950.46 and 960.39 (16th ed.). Arlington, Association of Official Analytical Chemists. Washington, DC, 1995.

22. G. Dadalı, D. Kilıc-Apar, B. Ozbek, Drying Technol, 2007, 25, 925-936. DOI:10.1080/07373930701372296

23. H. Isleroglu, T. Kemerli, M. Sakin Yilmazer, G. Guven, O. Ozdestan, A. Uren, F. Kaymak-Ertekin, J Food Sci, 2012, 77(10), E257-E263. DOI:10.1111/j.1750-3841.2012.02912.x

24. T. Alam, P. S. Takhar, J Food Sci, 2006, 81(3), 651-664. DOI:10.1111/1750-3841.13219

25. T. Altuğ, Y. Elmacı, Gıdalarda duyusal değerlendirme. Meta press, İzmir, 2005, p 130.

26. AOAC, Official Methods for Analysis, 15th ed. Vol. 2. Arlington, VA: Association of Official Analytical Chemists, 1990.

27. R. G. Moreira, M. E. Castell-Perez, M. A. Barrufet, Deep- Fat Frying: Fundamentals and Applications. Aspen Publishers, Gaithersburg, MD, USA, 1999.

28. G. Lisinska, G. Golubowska, Food Chem, 2005, 93, 681-687. DOI:10.1016/j.foodchem.2004.10.046

29. S. Romani, M. Bacchiocca, P. Rocculi, M. Dalla Rosa, J Food Compos Anal, 2009, 22, 582-588.

DOI:10.1016/j.jfca.2008.10.001

30. M. H. Gamble, P. Rice, LWT-Food Sci Technol, 1988, 21, 62-65.
31. B. Baumann, F. Escher, LWT-Food Sci Technol, 1995, 28, 395403. DOI:10.1016/0023-6438(95)90023-3

32. F. Pedreschi, P. Moyano, LWT-Food Sci Technol, 2005, 38, 599-604. DOI:10.1016/j.lwt.2004.08.008

33. P. Bouchon, Adv Food Nutr Res, 2009, 57, 210-334.

34. V. Dueik, M. C. Moreno, P. Bouchon, J Food Eng, 2012, 111, 528-536. DOI:10.1016/j.jfoodeng.2012.02.027

35. R. G. Moreira, P. F. Da Silva, C. Gomes, J Food Eng, 2009, 92, 297-304. DOI:10.1016/j.jfoodeng.2008.11.012

36. F. Pedreschi, K. Kaack, K. Granby, E. Troncoso, J Food Eng, 2007, 79(4), 1287-1294. DOI:10.1016/j.jfoodeng.2006.04.014

37. M. Yost, J. M. Abu-Ali, S.A. Barringer, J Food Sci, 2006, 71(9), 364-369. DOI:10.1111/j.1750-3841.2006.00171.x

38. P. C. Moyano, V. K. Rioseco, P. A. Gonzalez, J Food Eng, 2002, 54, 249-255. DOI:10.1016/S0260-8774(01)00211-4

39. L. M. Diamante, G. P. Savage, L. Vanhanen, Inter J Food Sci Technol, 2012, 47, 518-524.

DOI:10.1111/j.1365-2621.2011.02872.x

40. M. H. Gamble, P. Rice, Inter J Food Sci Technol, 1987, 22, 535548. DOI:10.1111/j.1365-2621.1987.tb00519.x

41. S. Paul, G. S. Mittal, Crit Rev Food Sci Nutr, 1997, 37, 635-662. DOI:10.1080/10408399709527793

42. R. Guillaumin, Kinetics of fat penetration in food. In Valera, A. E. Bender, I. D. Merlon,Frying of food. Chichester, UK: VCH, 1988.

43. M. K. Krokida, V. Oreopoulou, Z. B. Maroulis, J Food Eng, 2000, 44, 39-46. DOI:10.1016/S0260-8774(99)00163-6

44. A. Kita, G. Lisinska, J Sci Food Agric, 2005, 85, 2600-2604. DOI: $10.1002 /$ jsfa.2319

45. F. Pedreschi, C. Cocio, P. Moyano, E. Troncoso, J Food Eng, 2008, 87, 200-212. DOI:10.1016/j.jfoodeng.2007.11.031

46. P. Bouchon, J. M. Aguilera, D. L. Pyle, J Food Sci, 2003, 68, 2711-2716. DOI:10.1111/j.1365-2621.2003.tb05793.x

47. K. Grob, Food Addit Contam, Supplement, 2007, 24 (S1), 7181. DOI:10.1080/02652030701398509

48. F. Pedreschi, P. Moyano, K. Kaack, K. Granby, Food Res Inter, 2005, 38, 1-9. DOI:10.1016/j.foodres.2004.07.002

49. N. Surdyk, J. Rosén, R. Andersson, P. Åman, J Agric Food Chem, 2004, 52(7), 2047-2051. DOI:10.1021/jf034999w

50. E. Brathen, S. H. Knutsen, Food Chem, 2005, 92(4), 693-700. DOI:10.1016/j.foodchem.2004.08.030

51. H. Ölmez, F. Tuncay, N. Özcan, S. Demirel, J Food Compos Anal, 2008, 21, 564-568. DOI:10.1016/j.jfca.2008.04.011

52. F. Mestdagh, T. De Wilde, P. Castelein, O. Németh, C. Van Peteghem, B. De Meulenaer, Euro Food Res Technoly, 2008, 227(1), 69-76. DOI:10.1007/s00217-007-0694-9

53. F. Pedreschi, K. Kaack, K. Granby, Food Res Interl, 2006, 39, 40-46. DOI:10.1016/j.foodres.2005.06.001

54. V. Gökmen, T. K. Palazoğlu, H. Z. Şenyuva, J Food Eng, 2006, 77(4), 972-976. DOI:10.1016/j.jfoodeng.2005.08.030

55. T. Karadoğan, Atatürk Ü Zir Fak Der, 1994, 25 (1), 30-38.

56. Y. Yang, I. Achaerandio, M. Pujolà, Food Control, 2016, 62, 216-223. DOI:10.1016/j.foodcont.2015.10.028

57. T. K. Palazoğlu, D. Savran, V. Gökmen, J Food Sci, 2010, 75(1), E25-E29. DOI:10.1111/j.1750-3841.2009.01389.x

58. T. M. Amrein, S. Bachmann, A. Noti, M. Biedermann, M. F. 
Barbosa, S. Biedermann-Brem, et al., J Agric Food Chem, 2003, 51(18), 5556-5560. DOI:10.1021/jf034344v

59. G. O. Abong, M. W. Okoth, J. K. Imungi, J. N. Kabira, Am J Food Technol, 2011, 6(9), 753-762.

60. A. Kaur, N. Singh, R. Ezekiel, Int J Food Prop, 2008, 11: 791803. DOI: $10.1080 / 10942910701622664$

61. H. D. Isengard, Lipid Technol, 2010, 22(6), 134-136. DOI:10.1002/lite.201000019

62. R. Farhoosh, M. H. Tavassoli-Kafrani, Food Chem, 2010, 122: 381-385. DOI:10.1016/j.foodchem.2010.02.066

63. A. H. A. Tarmizi, K. Niranjan, Food Bioprocess Technol, 2013, 6:2600-2608. DOI:10.1007/s11947-012-0921-7
64. Anonymous, 2012, Kizartmada Kullanılmakta Olan Katı Ve Sıvı Yağlar İçin Özel Hijyen Kuralları Yönetmeliği, Retrieved from http://www.resmigazete.gov.tr/eskiler/2012/05/ 20120512-5.htm

65. A. H. Ahmad Tarmizi, L. İsmail, J American Oil Chem Soc, 2008, 85(3), 245-251. DOI:10.1007/s11746-007-1184-8

66. M. Bensmira, B. Jiang, C. Nsabimana, T. Jian, Food Res Inter, 2007, 40(3), 341-346.

DOI:10.1016/j.foodres.2006.10.004

67. J. B. Rossell, Frying: Improving Quality. Woodhead Publishing Limited, Cambridge, 2001, pp. 1-355.

DOI:10.1201/9781439822951

\section{Povzetek}

Testirali smo različne pogoje vakuumskega cvrtja pomfrita in preverjali njegove fizikalne, kemijske in organoleptične lastnosti glede na uporabljeno olje ter trajanje in temperaturo cvrtja. Da bi določil optimalne pogoje cvrtja smo pri študiji uporabili načrt s centralno zasnovo $\mathrm{z}$ rotacijo. Optimalni pogoji so vključevali minimalno vsebnost olja, trdoto v območju 30-45 N, minimalno vsebnost akrilamida in celovito ustreznost. Optimalne rezultate cvrtja pomfrita smo dosegli s temperaturo $124.39{ }^{\circ} \mathrm{C}$ in trajanjem $8.36 \mathrm{~min}$. Tako pripravljen pomfrit je ohranil željeno bravo, teksturne lastnosti in okus, vseboval pa je tudi malo olja in znižano tvorbo akrilamidov. Poleg tega se je pri vakuumskem cvrtju tudi ohranila kvaliteta olja.

Except when otherwise noted, articles in this journal are published under the terms and conditions of the Creative Commons Attribution 4.0 International License 